\title{
Revealing the Local Cathodic Interfacial Chemism Inconsistency in a Practical Large-Sized Li-O 2 Model Battery with High Energy Density to Underpin Its Key Cyclic Constraints
}

Gangning Zhang ${ }^{\mathrm{a}, \mathrm{b}, \mathrm{c}}$, Shigang Lu*a,b,c,d, Shangqian Zhao *a,b,c, Li Zhang ${ }^{\mathrm{b}, \mathrm{c}}$ and Haobo $\operatorname{Sun}^{\mathrm{b}, \mathrm{c}}$

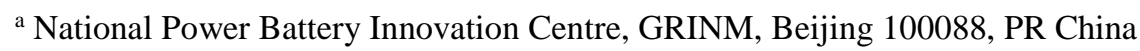

${ }^{\mathrm{b}}$ China Automotive Battery Research Institute Co. Ltd, Beijing, 101407, PR China

${ }^{\mathrm{c}}$ General Research Institute for Nonferrous Metals, Beijing 100088, PR China

${ }^{d}$ Materials Genome Institute, Shanghai University, Shanghai 200444, PR China

Corresponding authors: Shigang Lu (lusg8867@163.com) and Shangqian Zhao (zhaosq@glabat.com). 


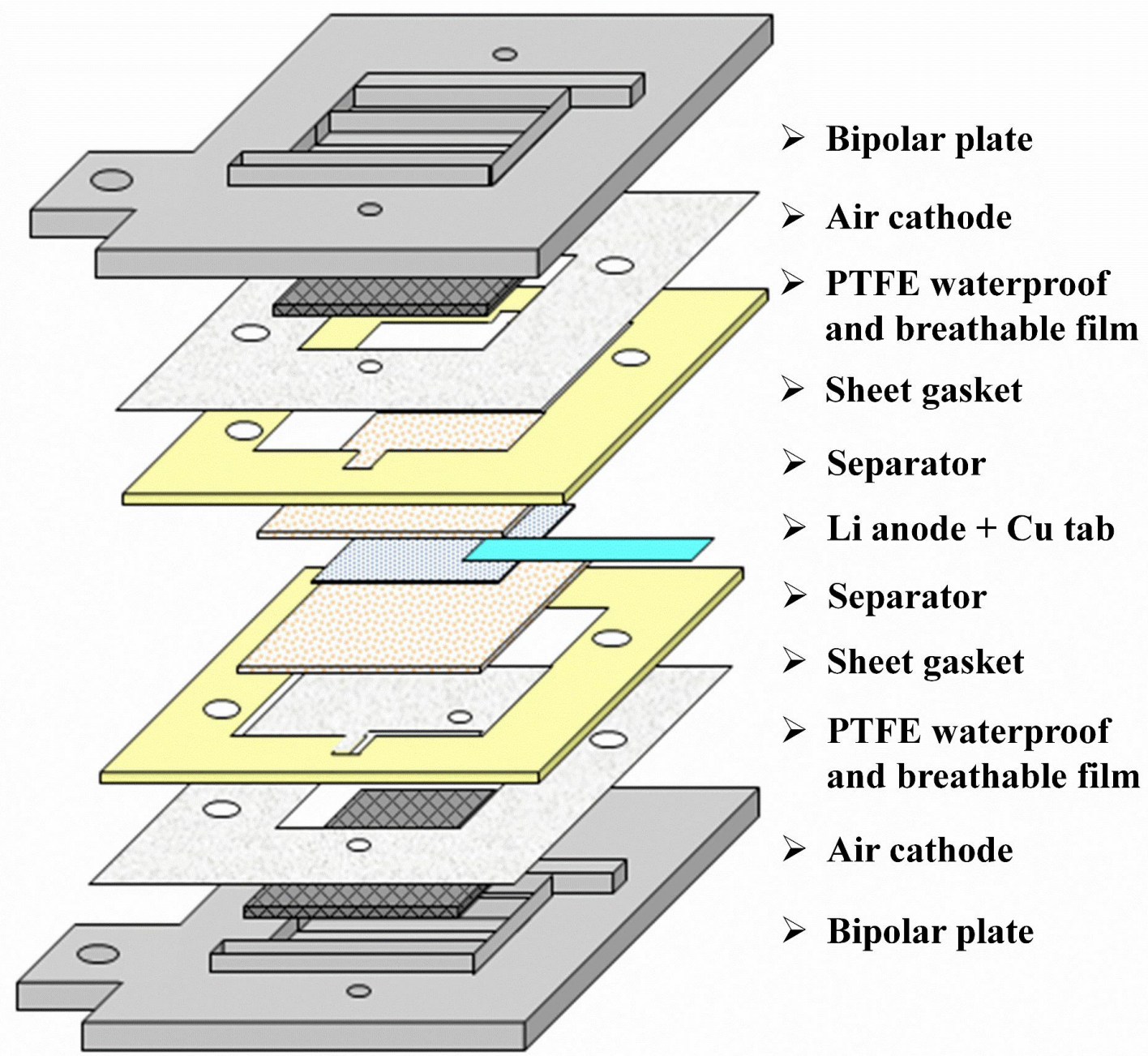

Figure S1. Schematic diagram of the structure design for fuel cell type $\mathrm{Li}^{-} \mathrm{O}_{2}$ battery

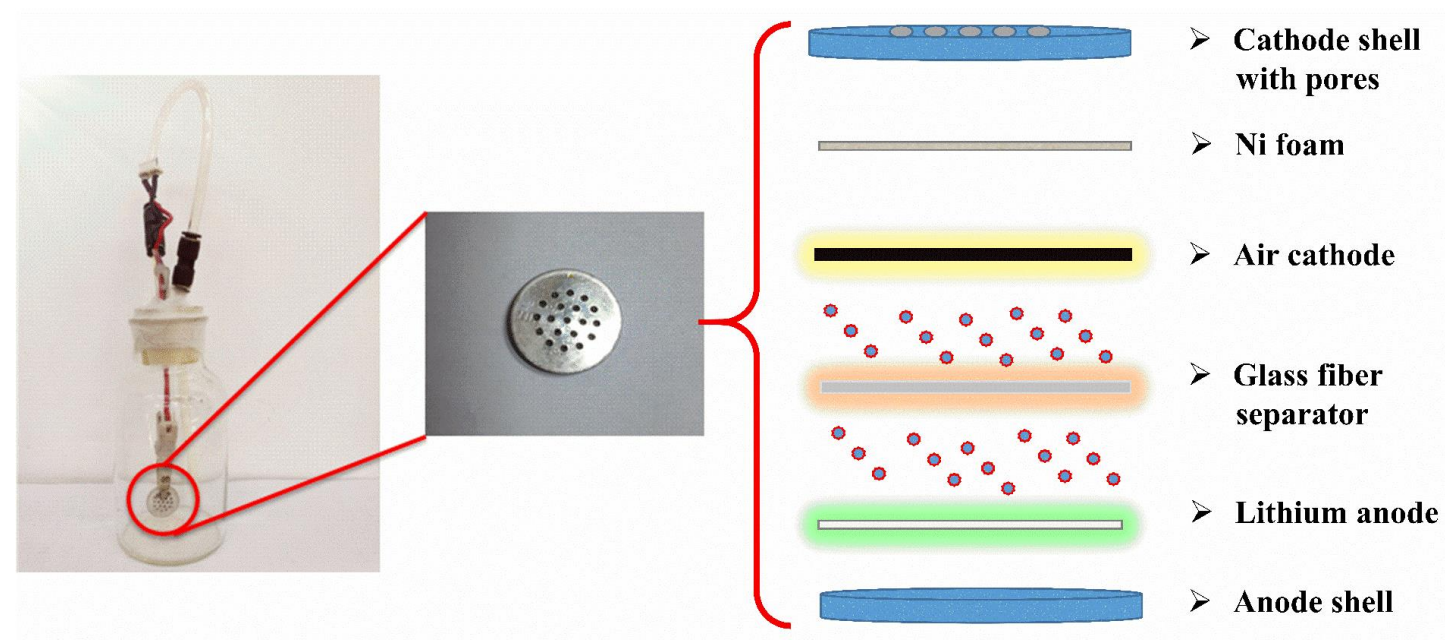

Figure S2. Diagram of the coin-type $\mathrm{Li}^{-\mathrm{O}_{2}}$ battery structure and the home-made bottle testing device 


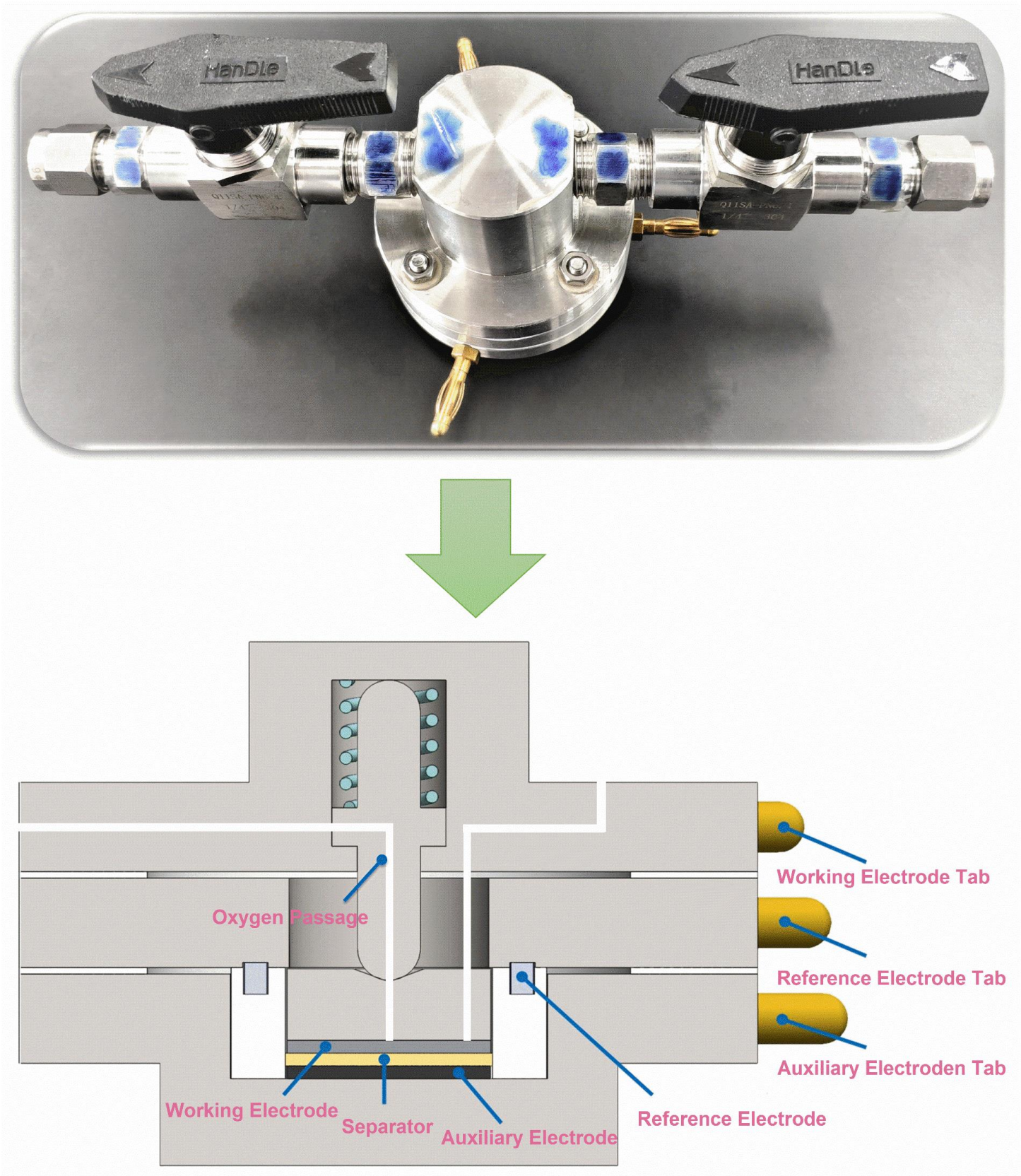

Figure S3. Physical map as well as diagrammatic sketch of the sectional view for the customized Swagelok-type three-electrode $\mathrm{Li}^{-} \mathrm{O}_{2}$ battery testing device. 

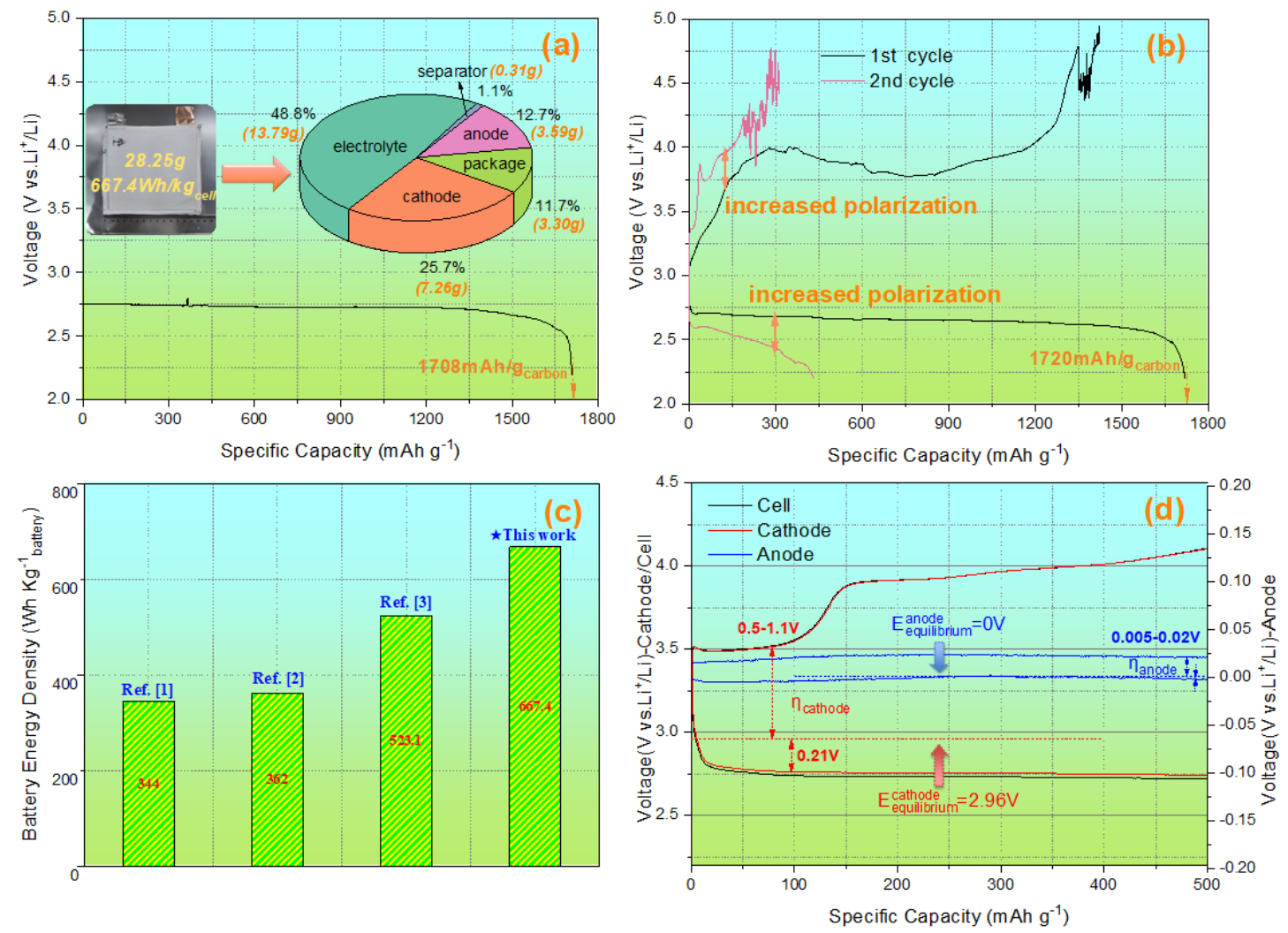

Figure S4. (a) Discharge voltage vs. the cathode specific capacity for the pouch-type Li- $\mathrm{O}_{2}$ battery with $2.2 \mathrm{~V}$ as the cut-off voltage, the inset pie chart gave the battery component weight ratio, and the picture showed the " $13 \mathrm{~cm} * 13 \mathrm{~cm}$ " sized battery, (b) cycling performance of the $13 \mathrm{~cm} * 13 \mathrm{~cm}$ pouch-type $\mathrm{Li}-\mathrm{O}_{2}$ battery, (c) comparison of the battery energy density in this work with different literatures, ${ }^{1,2,3}$ (d) three-electrode test of the Swagelok-type Li-O $\mathrm{O}_{2}$ battery to determine the cell, cathode, and anode polarizing voltages during discharge and charge.

\section{Notes:}

The three-electrode test in Figure S4d showed that the cathode can have an overpotential of $0.21 \mathrm{~V}$ and $0.5-1.1 \mathrm{~V}$ for discharge and charge, respectively, and the overpotential of the cathode was obviously larger than that of the anode $(0.005-0.02 \mathrm{~V})$. Thus, the overpotential of the cathode mainly occupied that of the whole $\mathrm{Li}^{-} \mathrm{O}_{2}$ battery. 
Table S1. Related technical parameters of the $667.4 \mathrm{Wh} / \mathrm{kg}$ battery.

\begin{tabular}{cccccc}
\hline $\begin{array}{c}\text { Capacity } \\
(\mathbf{m A h})\end{array}$ & $\begin{array}{c}\text { Energy } \\
(\mathbf{m W h})\end{array}$ & $\begin{array}{c}\text { Areal capacity } \\
\left(\mathbf{m A h} / \mathbf{c m}^{2}\right)\end{array}$ & $\begin{array}{c}\text { Run duration } \\
(\mathbf{h o u r})\end{array}$ & $\begin{array}{c}\text { Battery weight } \\
(\mathbf{g})\end{array}$ & $\begin{array}{c}\text { Specific energy } \\
\mathbf{( W h /} / \mathbf{k g})\end{array}$ \\
\hline 6923.64 & 18854.53 & 20.48 & 443.1 & 28.25 & 667.4 \\
\hline
\end{tabular}

\section{Notes:}

The specific energy density of $667.4 \mathrm{Wh} / \mathrm{kg}_{\text {cell }}$ was calculated based on the total weight of the $28.25 \mathrm{~g}$ cell (it didn't contain the weight of the outside Ni foam gas diffusion layer or SS clamps) shown in the inset picture of Fig.S4(a), and to be more clear, the cathode weight of $7.26 \mathrm{~g}$ included the weight of Al grid current collector, and the package weight of $3.30 \mathrm{~g}$ referred to the breathable PTFE film. And the detailed calculation process is as follows:

Battery specific energy density

$=18854.53 \mathrm{mWh} / 28.25 \mathrm{~g}_{\text {cell }}$

$=18854.53 \mathrm{mWh} /\left(13.79 \mathrm{~g}_{\text {electrolyte }}+0.31 \mathrm{~g}_{\text {separator }}+3.59 \mathrm{~g}_{\mathrm{Li}+\mathrm{Cu}}\right.$ tab $+3.30 \mathrm{~g}_{\mathrm{PTFE}}$ film +

$7.26 \mathrm{~g}_{\text {Super } \mathrm{P}}+\mathrm{Binder}+\mathrm{Al}$ grid $)$

$=667.4 \mathrm{Wh} / \mathrm{kg}_{\text {cell }}$ 

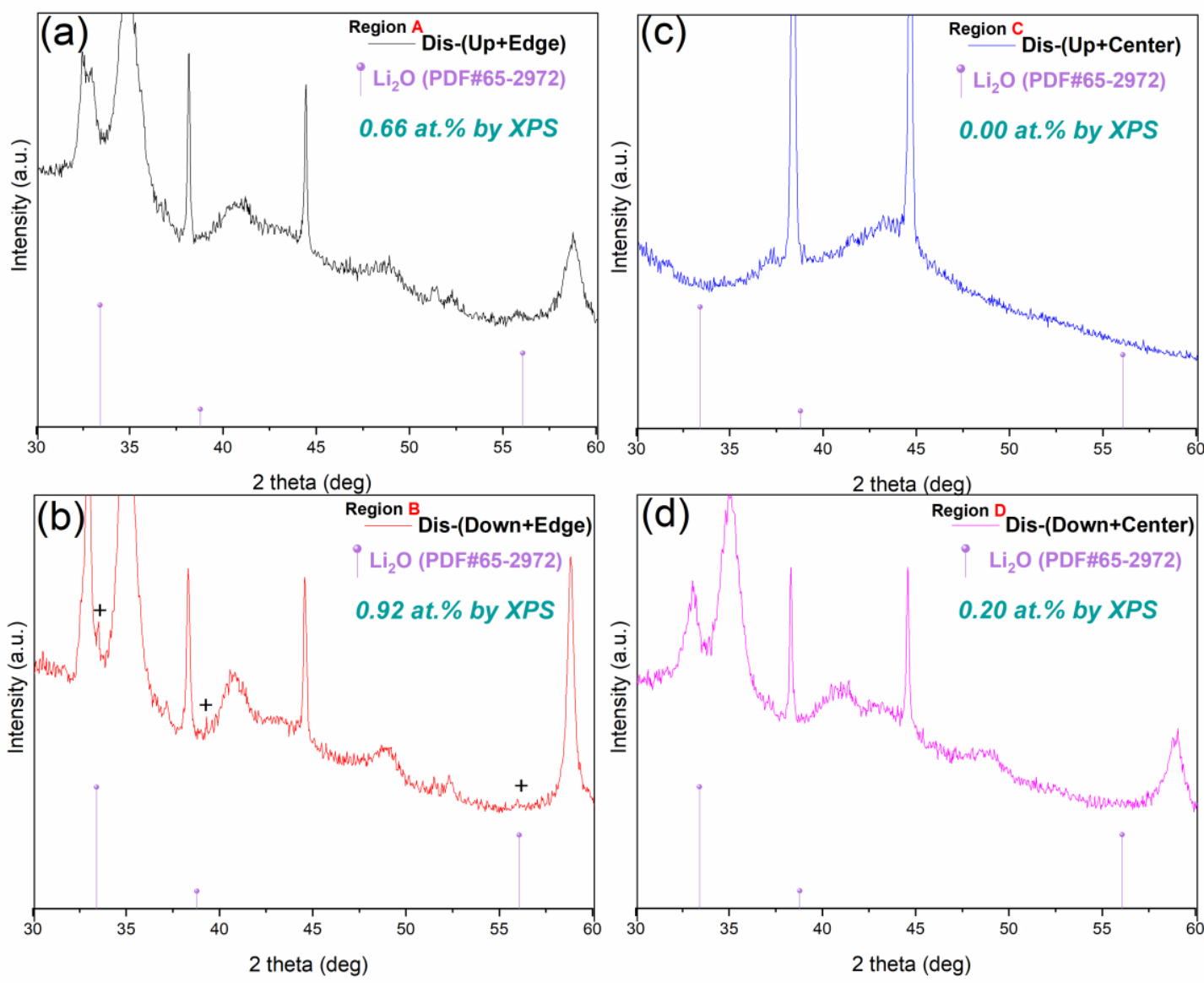

Figure S5. Enlarged XRD patterns for the four typical regions after discharge, and the corresponding atomic content of $\mathrm{Li}_{2} \mathrm{O}$ after discharge in the same region by XPS was also labelled. 

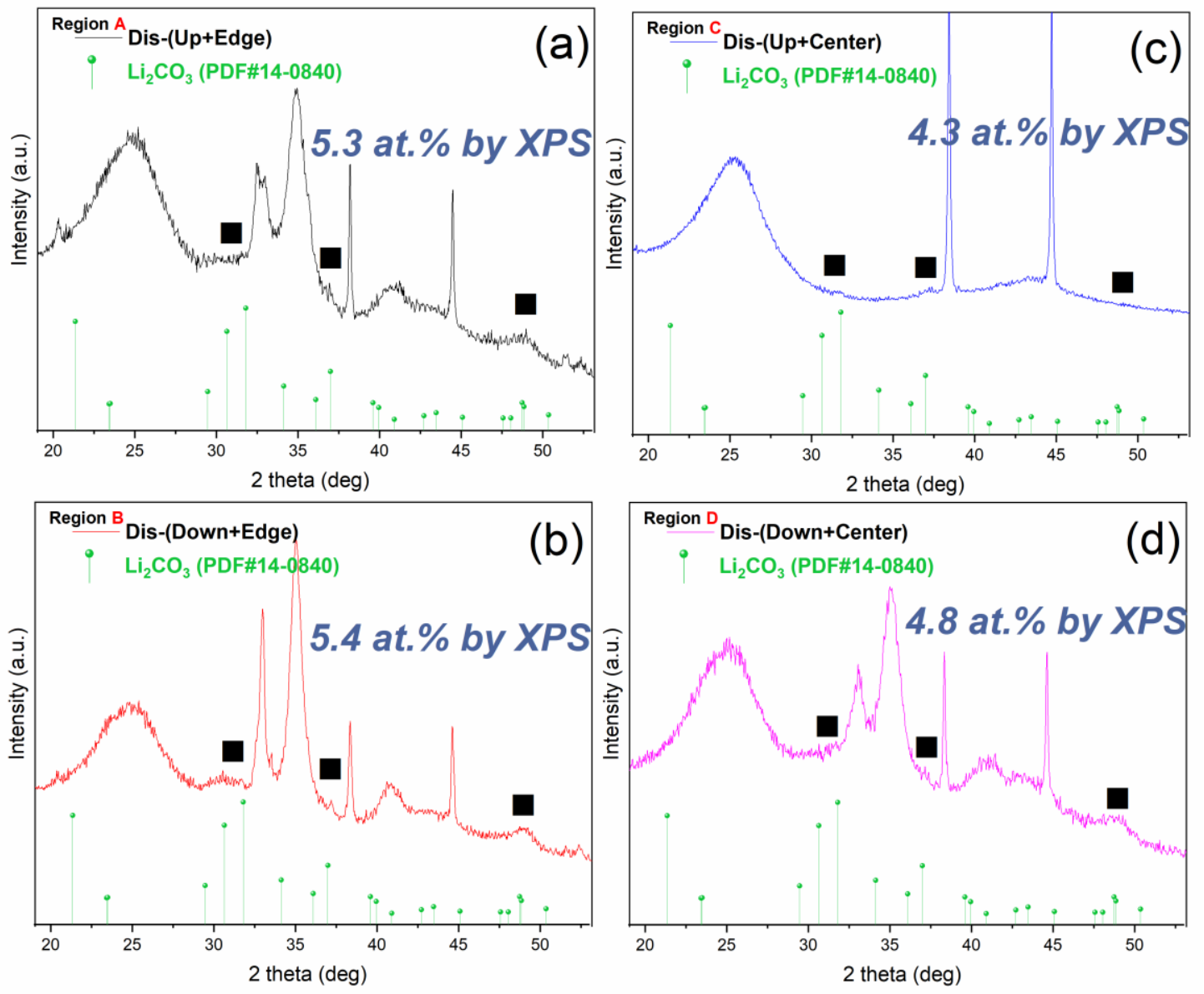

Figure S6. Enlarged XRD patterns for the four typical regions after discharge, and the corresponding atomic content of $\mathrm{Li}_{2} \mathrm{CO}_{3}$ after discharge in the same region by XPS was also labelled. 

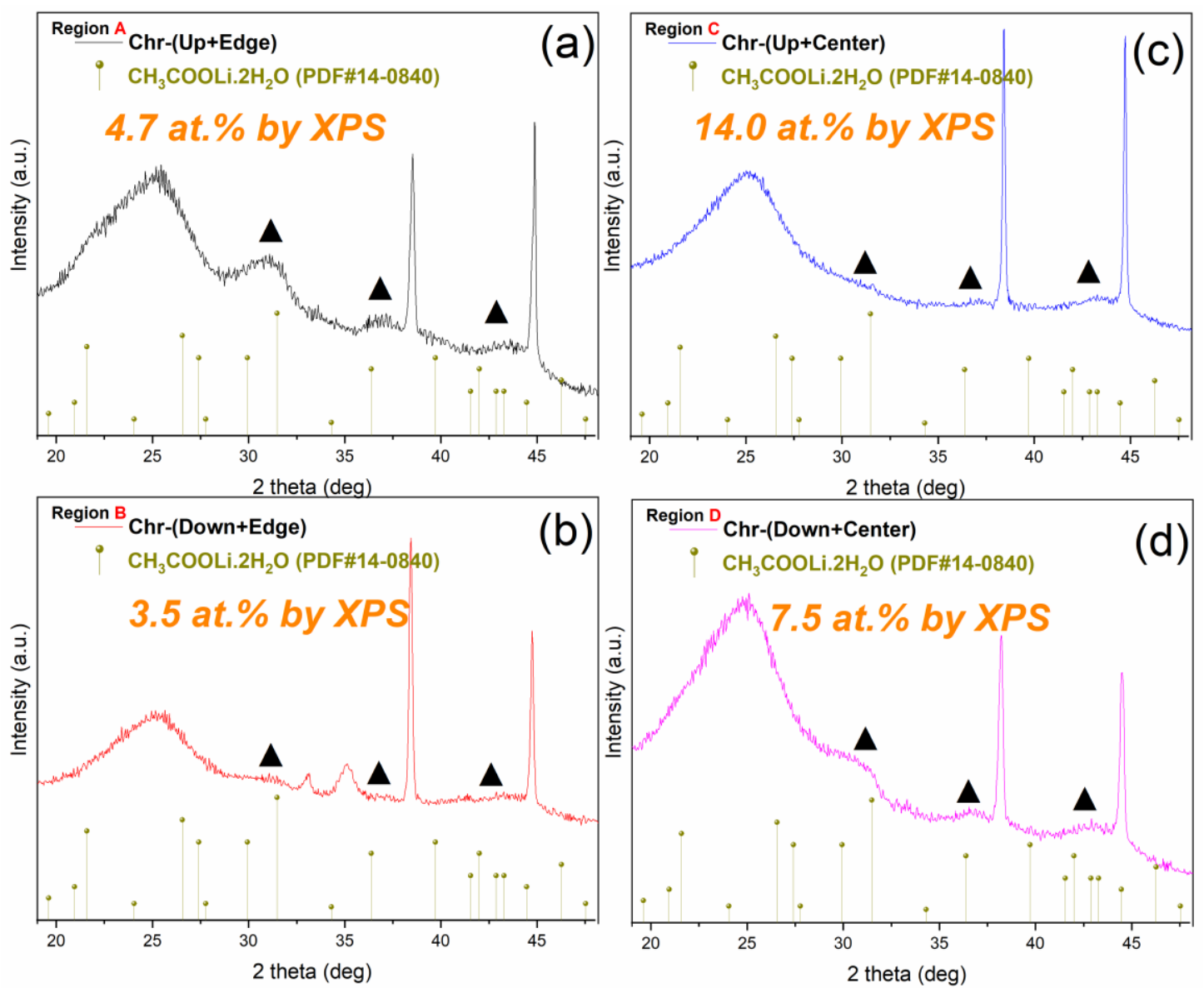

Figure S7. Enlarged XRD patterns for the four typical regions after charge, and the corresponding atomic content of " $\mathrm{CH}_{3} \mathrm{COO}-$ " after charge in the same region by XPS was also labelled.

\section{Notes:}

By comparison with the XRD patterns of $\mathrm{Li}_{2} \mathrm{CO}_{3}$ in Fig.S6, the peak signal of LiAc. $2 \mathrm{H}_{2} \mathrm{O}$ in Fig.S7 seemed not that sharp or strong when they $\left(\mathrm{Li}_{2} \mathrm{CO}_{3}\right.$ and LiAc. $2 \mathrm{H}_{2} \mathrm{O}$ ) shared an analogous atomic content (e.g., Fig.S6d and Fig.S7a) perhaps due to their crystallization degree differences in the electrolyte system, and this can be the reason for the relatively weak PDF card match of $\mathrm{LiAc} .2 \mathrm{H}_{2} \mathrm{O}$ in Region B. However, when the LiAc. $2 \mathrm{H}_{2} \mathrm{O}$ 's generation reached a higher content, especially for the value of 14.0 at.\% in Region C, it had a good match with the standard PDF card (PDF\#14-0840), and this further proved the formation and existence of $\mathrm{LiAc} .2 \mathrm{H}_{2} \mathrm{O}$ within the cathodes after the charge. 

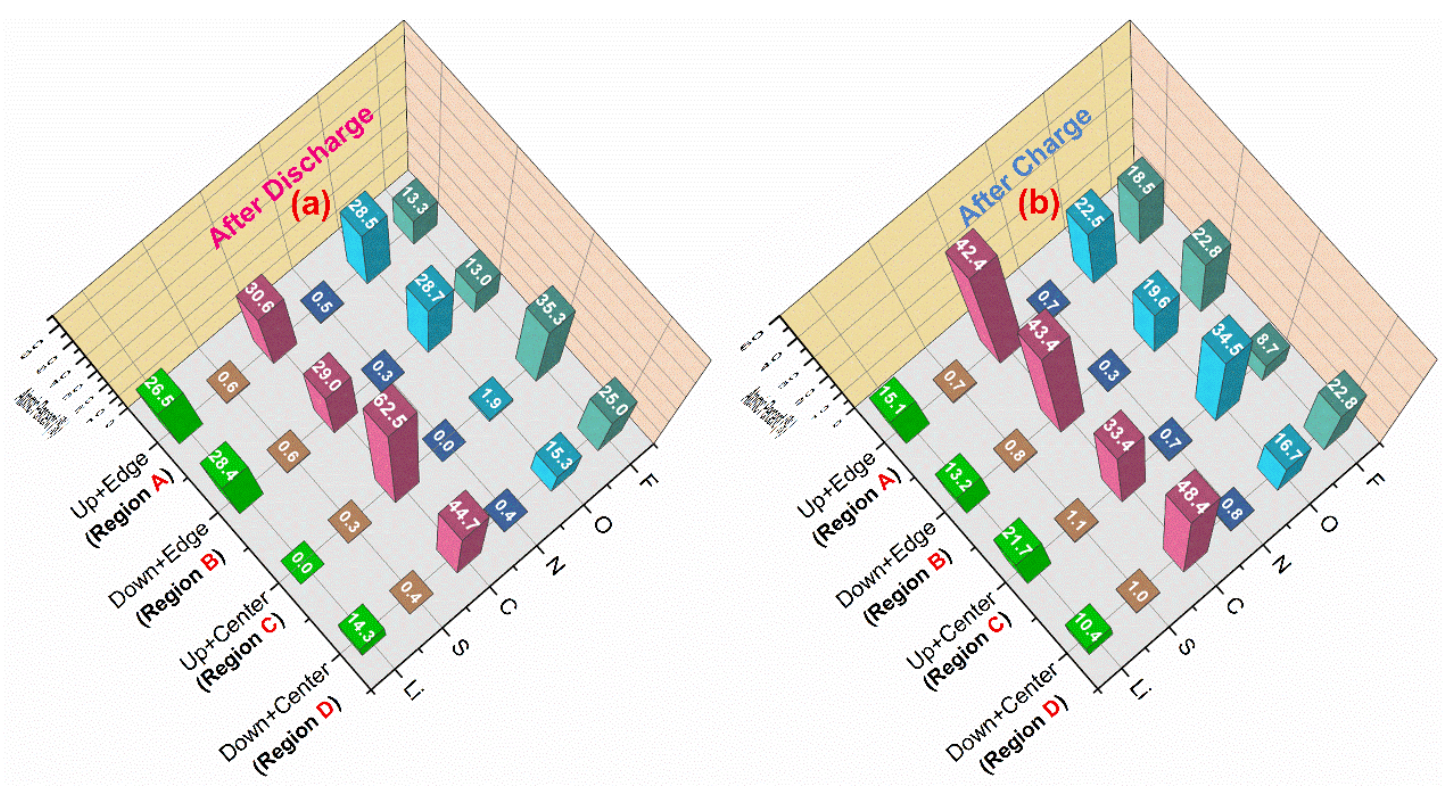

Figure S8. Atomic percentage of total F, O, N, C, S and Li for the cathodes in different regions after discharge (a)and after charge (b).

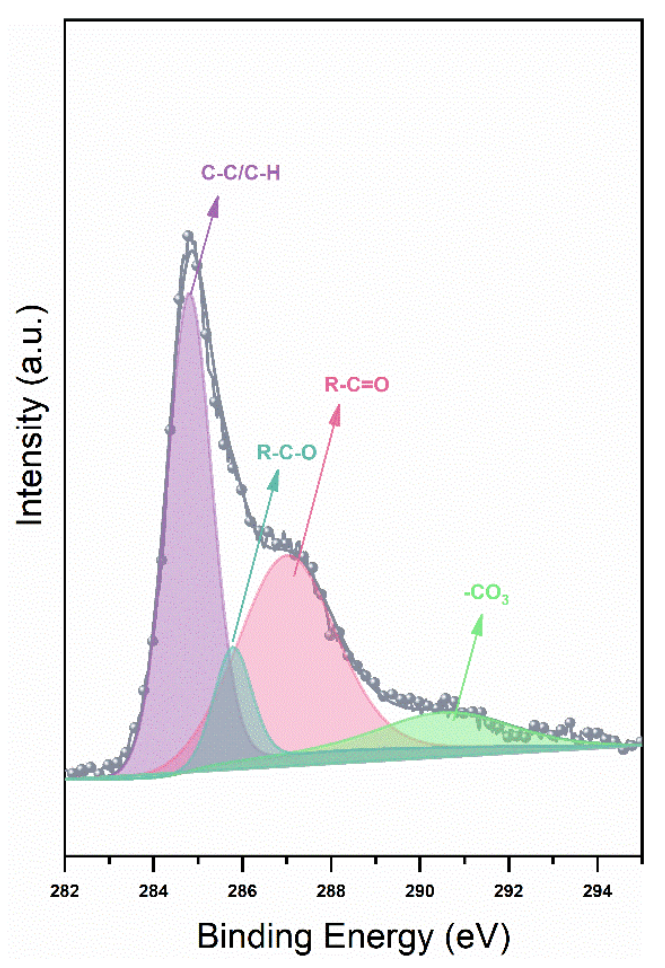

Figure S9. C 1s XPS analysis of the coin-type cell cathode after charge. 
Table S2. Relative atomic percent of $\mathrm{C}$ species in different regions after discharge

\begin{tabular}{cccccccccc}
\hline \multirow{2}{*}{$\begin{array}{c}\text { Cathode } \\
\text { Location }\end{array}$} & \multicolumn{7}{c}{ Atomic Percent of assigned C species after Discharge (at. \%) } \\
\cline { 2 - 10 } & Total C & $\mathrm{C}-\mathrm{C} / \mathrm{C}-\mathrm{H}$ & $\mathrm{C}-\mathrm{O}$ & $\mathrm{C}=\mathrm{O}$ & $\mathrm{CH}_{3} \mathrm{COO}-$ & $-\mathrm{CO}_{3}$ & $\mathrm{HCOO}-$ & $-\mathrm{CF}_{2}$ & $-\mathrm{CF}_{3}$ \\
\hline Region A & 30.62 & 15.35 & 2.83 & 2.74 & 0.00 & 5.32 & 0.00 & 4.38 & 0.00 \\
Region B & 28.99 & 13.93 & 2.39 & 3.11 & 0.00 & 5.43 & 0.00 & 4.13 & 0.00 \\
Region C & 62.50 & 35.74 & 4.64 & 3.98 & 0.00 & 4.33 & 0.00 & 0.00 & 13.81 \\
Region D & 44.69 & 19.50 & 8.86 & 3.70 & 0.00 & 4.76 & 6.71 & 1.16 & 0.00 \\
\hline
\end{tabular}

Table S3. Relative atomic percent of $\mathrm{C}$ species in different regions after charge

\begin{tabular}{lcccccccccc}
\hline \multirow{2}{*}{$\begin{array}{c}\text { Cathode } \\
\text { Location }\end{array}$} & \multicolumn{7}{c}{ Atomic Percent of assigned C species after Charge (at. \%) } \\
\cline { 2 - 10 } & Total C & $\mathrm{C}-\mathrm{C} / \mathrm{C}-\mathrm{H}$ & $\mathrm{C}-\mathrm{O}$ & $\mathrm{C}=\mathrm{O}$ & $\mathrm{CH}_{3} \mathrm{COO}-$ & $-\mathrm{CO}_{3}$ & $\mathrm{HCOO}-$ & $-\mathrm{CF}_{2}$ & $-\mathrm{CF}_{3}$ \\
\hline Region A & 42.44 & 13.26 & 9.61 & 6.20 & 4.74 & 0.00 & 7.78 & 0.00 & 0.84 \\
Region B & 43.42 & 12.43 & 9.73 & 7.37 & 3.49 & 0.00 & 9.27 & 0.00 & 1.13 \\
Region C & 33.39 & 8.91 & 4.67 & 4.15 & 13.99 & 0.00 & 0.00 & 0.00 & 1.67 \\
Region D & 48.39 & 19.02 & 9.04 & 4.01 & 7.47 & 0.00 & 0.00 & 0.00 & 8.85 \\
\hline
\end{tabular}

Table S4. Relative atomic percent of O species in different regions after discharge

\begin{tabular}{lcccccc}
\hline Cathode & \multicolumn{5}{c}{ Atomic Percent of assigned O species after Discharge (at. \%) } \\
\cline { 2 - 7 } Location & Total O & $\mathrm{Li}_{2} \mathrm{O}$ & $\mathrm{Li}_{2} \mathrm{O}_{2}$ & $\mathrm{C}=\underline{\mathrm{O}} / \mathrm{Li}_{2} \mathrm{CO}_{3} / \mathrm{LiOH}$ & $\mathrm{C}-\underline{\mathrm{O}}$ & $\mathrm{SO}_{2} \mathrm{CF}_{3}$ \\
\hline Region A & 28.50 & 0.66 & 11.59 & 11.74 & 4.50 & 0.00 \\
Region B & 28.68 & 0.92 & 13.35 & 9.06 & 5.35 & 0.00 \\
Region C & 1.86 & 0.00 & 0.00 & 0.64 & 0.44 & 0.78 \\
Region D & 15.29 & 0.20 & 4.06 & 5.33 & 5.70 & 0.00 \\
\hline
\end{tabular}

Table S5. Relative atomic percent of O species in different regions after charge

\begin{tabular}{ccccccc}
\hline Cathode & \multicolumn{5}{c}{ Atomic Percent of assigned O species after Charge (at. \%) } \\
\cline { 2 - 7 } Location & Total O & $\mathrm{Li}_{2} \mathrm{O}$ & $\mathrm{Li}_{2} \mathrm{O}_{2}$ & $\mathrm{C}=\underline{\mathrm{O}} / \mathrm{Li}_{2} \mathrm{CO}_{3} / \mathrm{LiOH}$ & $\mathrm{C}-\underline{\mathrm{O}}$ & $\mathrm{SO}_{2} \mathrm{CF}_{3}$ \\
\hline Region A & 22.52 & 0.00 & 0.00 & 15.18 & 5.02 & 2.32 \\
Region B & 19.57 & 0.00 & 2.98 & 8.67 & 5.92 & 2.00 \\
Region C & 34.46 & 0.00 & 0.00 & 28.13 & 4.14 & 2.20 \\
Region D & 16.72 & 0.00 & 0.00 & 8.38 & 4.76 & 3.58 \\
\hline
\end{tabular}




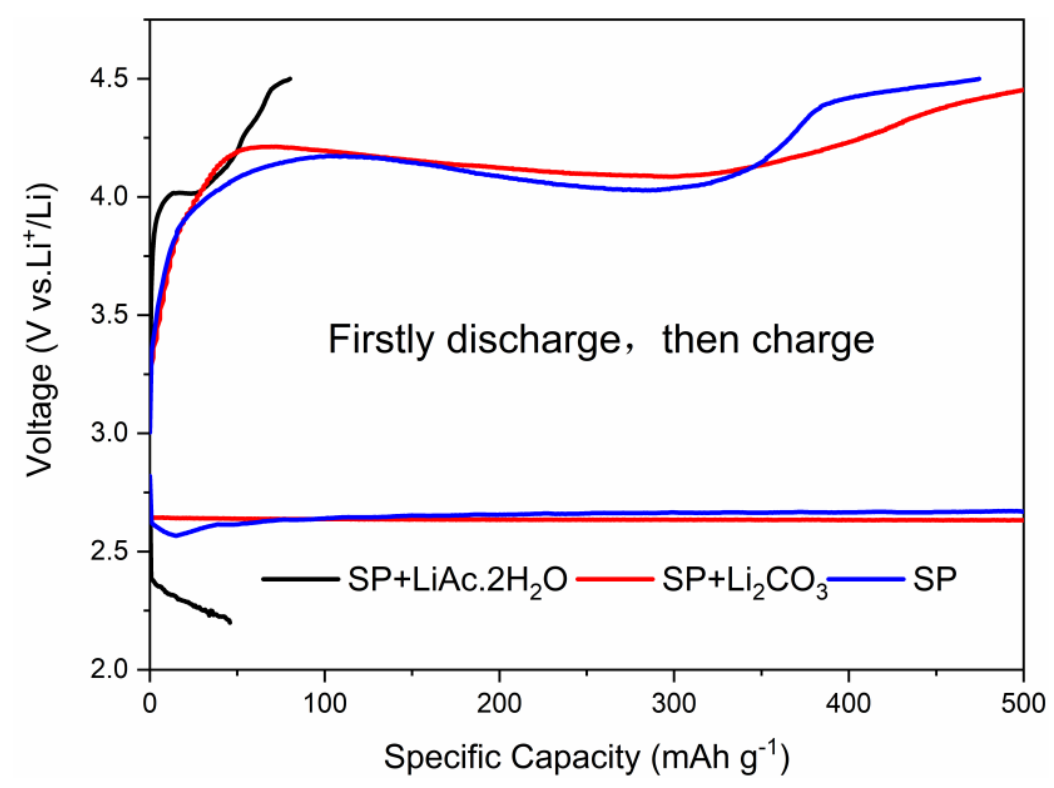

Figure S10. First cycle curve comparisons with "SP+LiAc. $2 \mathrm{H}_{2} \mathrm{O}$ ", " $\mathrm{SP}+\mathrm{Li}_{2} \mathrm{CO}_{3}$ ", and "SP" as the cathode material in coin-type $\mathrm{Li}^{-\mathrm{O}_{2}}$ battery following a "firstly discharge to $2.2 \mathrm{~V}$, then charge to $4.5 \mathrm{~V}$ " regime.

\section{References}

[1] Wang, D.; Xiao, J.; Xu, W.; Zhang, J. G. High Capacity Pouch-Type Li-Air Batteries. J. Electrochem. Soc. 2010, 157, A760-A764.

[2] Zhang, J. G.; Wang, D.; Wu, X.; Jibe, X.; Williford, R. E. Ambient operation of Li/Air batteries. J. Power Sources 2010, 195, 4332-4337.

[3] Liu, Q. C.; DP, Z. J.; Zhang, X.B. A Flexible and Wearable Lithium-Oxygen Battery with Record Energy Density achieved by the Interlaced Architecture inspired by Bamboo Slips. Adv. Mater. 2016, 28, 8413-8418. 